the first part of the Society's Journal would appear in September, and that it would contain a catalogue of all known papers giving information relating to the dates of publication of books on natural history. No such catalogue at present exists, and the publica. tion should be of value to all systematists. An item on the programme of the Society which it is hoped will be of great value to all naturalists is the publication of facsimiles of rare works of importance to natural history. The decision of the Society to maintain an information bureau for the use of its members is an indication of the present trend of societies to make available to the individual member the collective experience and knowledge of all. The annual general meeting of the Society will be held on the first Saturday in February.

\section{International Botanical Congresses}

A FEATURE of the sixth International Botanical Congress held at Amsterdam last September was the re-organization of the Botanical Section of the International Union of Biological Sciences and its recognition by the Congress as a liaison between successive International Congresses. Hitherto, each quinquennial congress has been independent of preceding congresses, and has been organized entirely by an ad hoc committee of the nation which was acting as host. Participation by other nationals in its various activities was by invitation. A drawback of this arrangement has been the absence of any body to ensure that resolutions passed by one congress were carried out and that committees appointed for definite objects were set to work. A circular has now been issued by the honorary secretary of the Botanical Section of the Union describing the aims of inter. national collaboration in science in general, and in particular defining the work of the Botanical Section in relation to successive congresses. The circular emphasizes the independence of the quinquennial congresses, the organization of which remains entirely in the hands of a national committee; but the various commissions and committees appointed by successive congresses will be adopted by the Botanical Section of the Union and thus "be united into a permanent, active and well-subsidized organization". This should ensure that work initiated at any one congress will be effectively carried out. For the present a definite liaison is suggested between the two organizations as the president of the Botanical Section of the Union, Prof. N. E. Svedelius, is vicepresident of the next International Congress to be held in Stockholm in 1940. The president of the Congress is Prof. R. E. Fries.

\section{Forestry Research in Canada}

As a result of recommendations made at a Conference on Forestry Research held in Ottawa in November 1935, the National Research Council of Canada has appointed a committee to study the requirements in respect to research in all branches of forestry, including measures for the better utilization of forest produsts. This committee is to function as an associate committee of the National Research
Council, and includes in its membership representatives of the Dominion Departments of the Interior and Agriculture, in addition to the National Research Council ; the forestry departments of each province ; members of the forestry faculties of universities in which there are departments of forestry; the lumber, pulp and paper and allied industries throughout the Dominion; the forest engineering societies; the forest protective associations and the Canadian Forestry Association. It is understood that the committee will base its preliminary programme on the findings of the Conference on Forestry Research held in November 1935 already alluded to. The importance of forestry and her forests to Canada needs no emphasizing. Much valuable work is being done already in the direction of research by federal and provincial agencies, individual companies and other organizations. The new committee will bring together data on the work at present in progress, correlate the information thus obtained, investigate the need for further research, and so forth. It is evidence of broad and statesman-like views among those responsible for the formation of the committee that representatives of all sides of forestry interests are included. In Great Britain, the position is far otherwise-research work is too often relegated to water-tight compartments, energies being thus dissipated; forestry committees are not fully representative of all sides of forestry ; whilst representatives of the individual forestry staffs of the universities as a whole do not automatically find places on forestry research committees.

\section{Control of Rabbit Infestation by the Use of a Virus}

OF all the pests from which the pastoral industry in Australia has suffered, rabbit infestation is probably the most serious economically, and little permanent success seems to follow the methods of control in use at present, such as trapping and poisoning. One hope would appear to lie in the discovery of some infectious disease, deadly to the rabbit but innocuous to man and other animals, and easily communicable to, and spreading widely by natural means among, the rabbits. Sir Charles Martin, as a result of an experimental inquiry, suggests that a disease 'rabbit myxomatosis' may fulfil these requirements (Commonwealth of Australia. Council for Scientific and Industrial Research, Bull. No. 96. Melbourne, 1936). This is an infectious, highly fatal, febrile disease caused by an ultra-microscopic virus, causing mucinous discharges, swellings and tumours in affected animals, fatal within twelve days or so, transmitted sufficiently by contact, and with a fatality of almost a hundred per cent. It attacks animals of the genus Oryctolagus, to which wild rabbits in Europe and Australia, and domesticated rabbits in Europe and America, belong; but it does not affect the indigenous rabbits of America, or man and other animals and birds. Experiments were conducted by Sir Charles Martin in a pen measuring 50 yards $\times 10$ yards, with both tame and wild rabbits. A colony having been established for three weeks or thereabouts, one or two rabbits inoculated 